\title{
Bare-root Planting Season Options
}

\author{
by
}

\author{
R.F. Sutton ${ }^{1}$
}

\section{Abstract}

Options are available to the forest manager who needs to extend the planting season beyond the textbook ideal of spring planting of freshly lifted stock that is dormant or apparently so. Bare-root planting season options are discussed under: conventional spring planting with fresh, spring-lifted stock; conventional fall planting with freshlifted stock; summer planting with fresh-lifted stock; and spring and summer planting with (i) spring-lifted stock, and (ii) fall-lifted stock.

For pines, whether or not stored before planting, the performance of outplants is shown to depend greatly on when and in what condition the stock was lifted. Lateness in fall lifting is critically important for pines. Provided that handling and planting quality are flawless, there is considerable scope for extending the conventional seasons of planting, e.g., with summer planting of spruces. Use of stored fall-lifted and spring-lifted stock offers an effective means of extending the spring planting season well into summer.

\section{Résumé}

Diverses possibilités s'offrent au gestionnaire forestier qui doit allonger la saison de plantation au-delà de l'idéal théorique qui est la plantation au printemps de lants fraîchement arrachés, dormants, du moins en apparence. Les possibilités pour la plantation de matériel à racines nues sont examinées dans diverses rubriques: plantation classique au printemps de plants fraîchement arrachés; plantation classique à l'automne de plants fraîchement arrachés; plantation en été de matériel fraîchement arraché; et plantation au printemps et en été i) de plants arrachés au printemps, et ii) de plants arrachés à l'automne.

Dans le cas des pins, qu'ils aient été ou non stockés avant la plantation, leur comportement se révèle fortement déterminé par le moment et les conditions de l'arrachement: tard l'automne, cette opération est d'importance critique. A condition que la manutention et la plantation soient sans défaut, ou peut considérablement prolonger la période transitionnelle de plantation, par exemple, celle des épinettes l'été. L'utilisation de matériels arrachés l'automne et le printemps, puis emmagasinés, offre un bon moyen de prolonger la période printanière de plantation très avant dans l'été.

\section{Introduction}

The classical silvicultural literature unanimously advocates spring as the time to plant bare-root stock, with lifting and outplanting taking place while the trees are still apparently dormant. This view, in which spring lifting is implicit, was epitomized by Toumey and Korstian (1942): "Almost without exception the most favorable time for ... planting is two weeks or more before buds [of the planting stock] begin their growth".

If the size of the planting program allows, there is little doubt that planting should be carried out in this manner. It satisfies one and commonly two of the factors essential for success: the use of planting stock that is physiologically capable of responding to a growth environment at planting, and planting when site factors favor tree survival and growth (Ryker 1976). The third factor, a good planting job, desirable in all plantings, is probably somewhat less critical in conventional spring plantings than in others.

'Department of the Environment, Canadian Forestry Service, Great Lakes Forest Research Centre, P.O. Box 490, Sault Ste. Marie, Ontario P6A 5M7.
If, however, a planting program cannot be completed in this way, additional means must be used. The present paper offers an evaluation of the various options open to forest managers planting bare-root jack pine (Pinus banksiana Lamb.), black spruce (Picea mariana [Mill.] B.S.P.) and white spruce ( $P$. glauca [Moench] Voss) in boreal and cool temperate forest regions.

The options that will be considered are: conventional spring planting with fresh, spring-lifted stock; conventional fall planting with fresh-lifted stock; summer planting with fresh-lifted stock; and spring and summer planting with stored (i) springlifted stock and (ii) fall-lifted stock. Discussion of each option is concluded with capsule recommendations.

No season of planting is free of periods of weather inimical to outplant survival and growth. Even outside of such periods, the weather on any given day of planting may determine plantation performance for a rotation (cf. Mullin 1971), as may a brief episode of stock mishandling. Any planting program must inevitably suffer severe losses if it is so inflexible as to require planting to continue even when weather or site condi- 
tions are highly stressful to lifted or newly outplanted stock. The major objective of efforts to extend to planting season is increased flexibility.

\section{Conventional Spring Planting with Fresh, Spring-lifted Stock}

\section{(a) The spring planting season}

In the context of regeneration silviculture, "spring", "summer", and "fall", lack precise meaning. The spring planting season typically begins as soon as lifting becomes possible in the nursery, and it ends with the completion of the spring planting program (Sutton 1982). Therefore, the length of the spring planting season depends on the size of the program (usually decided one or more years earlier on the basis of an educated guess as to how much planting can be done before flushing of planting stock becomes far advanced) and the size and productivity of the labor force employed to carry it out.

\section{(b) Advantages}

Spring planting with freshly lifted stock is the option conventionally preferred in cool temperate and boreal forest regions. The textbook ideal (cf. Köstler 1956) is to lift and outplant stock while it is still dormant or at least apparently so. At this time, planting stock is physiologically attuned to the oncoming growing season, and the outplant has the whole of that season in which to establish a root system before it is tested by any frost heaving, a factor of particular importance in fine-textured or poorly drained soils (Rudolf 1950).

\section{(c) Discussion}

In practice, ideals are seldom if ever attainable. That stock is normally dormant when planted is a widespread fallacy, at least in the case of spring lifting. In fact, active growth is commonly obvious at the time of lifting (Jorgensen and Stanek 1962, Stiell 1976). Furthermore, metabolic activity increases in planting stock before the tops give visible expression to this (Ryker 1976). The difficulty of obtaining, in quantity, springlifted stock that is dormant increases as the climate becomes increasingly continental. In many areas, the period of springlike weather is unreliable and often short (LeBarron et al. 1938, Toumey and Korstian 1942).

The soil moisture advantage claimed for spring planting is also insecurely founded. Snow melt does not necessarily assure a plentiful supply of soil moisture for newly planted stock. In particular, the moisture status at the time of planting of soils that are sandy or gravelly, and shallow soils of any texture, are highly dependent on current weather because of their limited available water capacities.

Furthermore, a plentiful supply of soil moisture will not benefit an outplant whose roots are enveloped in anaerobic and/or cold soil (Sutton 1969, Daniel et al. 1979). Soils that are wet, clayey, or well insulated by a layer of organic matter, warm up slowly in the spring, and mortality among trees outplanted into soil colder than about $6^{\circ} \mathrm{C}$ may be excessive (Sutton 1968). To delay planting of these sites with fresh-lifted stock until soil temperatures have risen above $6^{\circ} \mathrm{C}$ would virtually guarantee that planting stock will already have flushed before use.

\section{(d) Time of lifting/planting}

This subject is discussed separately because its influence on plantation performance is often underrated. The spring planting season is not homogeneous. Several major growth factors, including day length, air temperature, soil temperature, and the nature and intensity of competition from other vegetation, change progressively through the season. Also, annual variation in weather is considerable, and spring-like weather may last for all, most, or little of the spring planting season. The transition from winter-like to summer-like weather may be continuous or not, slow or rapid. All this has profound physiological and phenological effects on planting stock, notably in terms of root growth capacity and flushing.

In spring-lifted stock, the dormant condition will be most closely approached in stock lifted and planted early in the season. Flushing increases the vulnerability of planting stock to both physiological stress (because of increased water requirements and reduced root growth capacity) and mechanical damage. This probably accounts for the commonly reported superiority of early spring planting - provided that cold soils are avoided - over late spring planting (cf. Show 1930, Hawley and Smith 1954, Ackerman and Johnson 1962, Mullin 1971, Schubert and Adams 1971, Mullin and Reffle 1980).

If the lifting/planting of non-dormant stock is detrimental to outplants, one might expect sequential plantings through the spring planting season, before and after flushing, to show a progressive decline in performance.

This decline seems to be generally the case with pines (cf. Bunting and Mullin 1967, Mullin 1974b, Mullin and Forcier 1976, Mullin 1978a, Mullin and Reffle 1980), both survival and increment decreasing sharply with increasing lateness of planting.

With the spruces, the evidence is harder to interpret. A few studies (e.g., Mullin and Forcier 1976) suggest a similarity with pines. More studies (e.g., Burgar and Lyon 1968, Mullin 1971, Revel and Coates 1976, McClain 1979, 1981) indicate that, provided that the period of most active shoot elongation is avoided, spruces may be successfully planted throughout the spring planting period (and, as will be shown in a subsequent section, virtually throughout the growing season) with little loss of performance other than some reduction in increment.

Mullin's (1971) study at Midhurst in southern Ontario illustrates not only the success with which white spruce can be planted throughout the period in question, but also the need to minimize stresses on the planting stock. Mullin used $3+0$ stock from regular shipping beds in a series of six weekly plantings beginning with apparently dormant trees on 3 May and ending on 7 June, by which time the new shoots were several centimetres long. Trees were lifted and, with or without root dipping, planted on the day of lifting after their root systems had been exposed for $0,1,2$, or 3 hours. Whereas 2 nd-year survival in the control (root exposure $=0$ ) condition varied little among the six plantings, with averages of $83.5 \% \pm 4.7 \%$ for root-dipped trees and $77.2 \% \pm 7.0 \%$ for non-dipped, mortality rates among root-exposed stock were very much more variable. For instance, 2nd-year survival among root-dipped trees whose root systems had been exposed for 1 hour varied from $17 \%$ to $84 \%$. Trees that had been stressed by exposure of root systems were less able than others to withstand additional, weather-related stress.

\section{(e) Recommendations}

With pines, lifting and planting of fresh stock should be completed as early in the planting season as possible. With spruces, lifting and planting of fresh stock should be avoided during the period of most active shoot elongation. With all species, stress should be minimized, e.g., by good handling, good, prompt planting, and planting only in those soils that are moist, aerated, and warm enough to support vigorous growth of roots.

\section{Conventional Fall Planting with Fresh-lifted Stock} (a) The fall planting season

The fall planting season is generally considered to begin 
when nursery stock has hardened off and after soil moisture reserves have been replenished by autumnal rains. It then continues until the planting program has been completed or is terminated by freeze-up or heavy snow (cf. Revel and Coates 1976).

\section{(b) Advantages}

In some circumstances, fall planting can be successful. In the early decades of the present century, for instance, the advantages of fall planting were considered to "outweigh those of spring so certainly" that in the National Forests of the Lake States almost all planting was done in the fall (Kittredge 1929). Certainly, as LeBarron et al. (1938) have pointed out, soil moisture levels and soil temperatures may be just as favorable for plant growth in the fall as in the spring. If restricted to sandy soils that are not subject to frost heaving, fall planting can be used successfully to improve the flexibility of the planting program and work load scheduling.

\section{(c) Discussion}

In spite of some success, operational fall plantings in North America have tended to be less successful than operational spring plantings (LeBarron et al. 1938, Schopmeyer 1940). In eastern Ontario, for instance, fall planting was discontinued after unpredictable and disappointing results even in years with seemingly favorable weather and on good planting chances (Campbell 1977).

On certain sites, a major disadvantage of fall planting is that the root systems of outplants have little time in which to become firmly anchored before they are subjected to frost heaving (Hawley and Smith 1954). Insecurely rooted outplants are also very susceptible to "winter" browning, which in fact may occur in the fall soon after planting, especially among stock with high shoot:root ratios (Rudolf 1950).

The desire to prolong the time available for root system development in fall-planted stock led to the seemingly logical view that, as long as soil moisture is adequate, the sooner that outplanting is carried out in the fall, the warmer the soil will be and the greater the root growth, and consequently the outplant will be better able to resist any frost heaving. This may be true for spruces, but many early fall plantings of pines have been dramatically unsuccessful (cf. Baldwin 1938a, LeBarron et al. 1938, Sinclair and Boyd 1973). Baldwin's (1938b) experimentation led him to conclude that hard pines "obviously never should be planted in the fall". In a study with $2+1$ jack pine in Ontario, however, Bunting and Mullin (1967) showed that fall planting could be almost as successful as spring planting in terms of survival, although reassessment after 15 years showed that the growth of spring-planted trees had been significantly greater than that of fall-planted trees.

In addition to physiological changes, considerable changes in tree mass occur in planting stock between early and late fall or the following spring (Armson 1960, Mullin 1968, Bunting 1977): in southern Ontario, a tree in the nursery may double in mass between the beginning of September and the following spring. Nominally identical, trees of a given stock type and lot for spring planting may differ significantly in mass depending on whether they are fall- or spring-lifted.

Nevertheless, apart from frost heaving, physiological condition is probably the main factor determining performance among fall-planted stock. At least in Douglas-fir (Pseudotsuga menziessi [Mirb.] Franco) and ponderosa pine (Pinus ponderosa Laws.) (Lavender and Cleary 1974), almost certainly in the pines generally, and probably in other species as well. completion of dormancy requirements is necessary if subsequent root growth is to be adequate. For success in planting, trees must be physiologically capable of responding to a growth environment at planting (Ryker 1976). In other words, an outplant must be able to use a favorable growth environment into which it is introduced.

Hermann (1967), working with Douglas-fir, found that sensitivity to exposure of roots decreased through the fall and reached a minimum in winter, apparently in concert with the dormancy progression. Similar relationships may occur in other species. Handling procedures are therefore most critical in early fall plantings.

The relationships between dormancy progression and physiological condition, including root-growth capacity, are much less clear in the spruces than in the pines. Certainly there is good evidence (cf. Baldwin 1938b, Mullin 1968, Sinclair and Boyd 1973, and McClain 1975, 1981) that, in the absence of frost heaving, plantings of spruces may be just as successful in fall as in spring.

\section{(d) Recommendations}

With pines, fall planting is best avoided, but if done the stock must be lifted late enough to have reached a suitable physiological condition. With spruces, good results are possible. In all fall plantings, soils subject to frost heaving should be avoided, stock with a high shoot:root ratio should not be used, and handling/planting procedures should be such as to minimize the stresses imposed on the stock before, during, and after planting.

\section{Summer Planting with Fresh-lifted Stock (a) The summer planting season}

In the context of regeneration silviculture, summer is the period between the conventional spring and fall planting seasons.

\section{(b) Advantages}

Conceptually and logistically, the simplest way of extending the conventional planting season is to extend lifting and planting of fresh stock from spring through summer until the planting program has been completed. There is ample evidence that spruces may be planted successfully throughout the summer.

\section{(c) Discussion}

With pines, the possibilities of this approach are not promising (cf. Bunting and Mullin 1967, Mullin 1974b, 1978a), but summer planting has been remarkably successful in a number of research studies with white spruce (cf. Crossley 1956, Ackerman and Johnson 1962, Decie 1962 cited by Revel and Coates 1976, Burgar and Lyon 1968, Mullin 1971, 1974a, and Revel and Coates 1976) and black spruce (McClain 1975, 1981).

Non-dormant, actively growing stock is far less tolerant of stress than is dormant stock. Desiccation, overheating, root exposure, low atmospheric relative humidity, low levels of available soil moisture, and mechanical injury must all be studiously avoided. Planting should follow lifting with a minimum of delay. All the precautions applicable to conventional, dormant planting stock must be intensified for non-dormant stock. The successes achieved with research plantings of spruces through the summer cannot possibly be approached unless the sum total of stresses is kept as small as possible.

\section{(d) Recommendations}

Summer planting of fresh-lifted pines is not recommended. Spruces may be planted throughout the summer provided that stresses to planting stock are minimized at all stages, from lifting through planting, and trees are planted when site conditions are conducive to survival and growth. Though operationally difficult, minimization of stress must be achieved by 
field staff if summer planting is to be successful. Ideally, lifting (from moist soil) and outplanting (into moist soil) should take place on the same day.

\section{Spring and Summer Planting with Stored Stock (a) Refrigerated storage}

Refrigerated storage of planting stock (cf. Hocking and Nyland 1971) has been developed largely with the aim of overcoming problems attending the use of flushed planting stock. In broad terms, storage provides a means of holding stock for use when fresh stock is either unavailable or at a stage of development that renders it unsuitable for planting (cf. Williams and Rambo 1967, Slayton 1970).

Although storage of planting stock is by no means new (cf. Hopkins 1938, Leslie 1945), interest in it has intensified over the last 15 years or so as a result of expanded planting programs, labor supply difficulties, and an increasing appreciation of the possibilities of using storage practices to manipulate the physiological condition of the stock planted.

Also, storage of stock may be used as a means of reducing spring frost damage to newly outplanted stock (cf. Leslie 1945 , Jorgensen and Stanek 1962, Schmidt-Vogt 1963), either by planting late with unflushed stock in preference to flushed fresh-lifted stock or by taking advantage of the delay in flushing exhibited by stock after refrigerated storage (cf. Brown 1971, Nyland 1974)

As soon as storage enters the picture, however, so does another set of problems. Prolonged storage of planting stock may bring on mold, cold injury, desiccation, and depletion of food reserves. The rate of deterioration depends very much on the physiological condition of the planting stock at time of lifting (cf. Stoeckeler and Jones 1957, Simon 1961), as well as on the storage environment and duration of storage.

Sub-freezing temperatures give almost complete control of mold, but in cool storage, maintenance of a constant temperature just above freezing is probably the most effective way of minimizing the problem (Hocking and Nyland 1971). Pentachlorophenol has also been used successfully (Björkman 1956). Navratil et al. (1975) have stressed the importance of keeping foliage clean and dry, of proper packaging, and of good sanitation.

Cold injury to planting stock in frozen storage is important chiefly in that roots are normally the least hardy parts of plants (Levitt 1980). Planting stock in storage has on occasion survived temperatures as low as $-15^{\circ} \mathrm{C}$ (cf. Yli-Vakkuri et al. 1968 ), but in some circumstances $-5^{\circ} \mathrm{C}$ can be lethal (cf. Cram and Lindquist 1981). Temperatures lower than $-2^{\circ} \mathrm{C}$ would seem to offer only disadvantages.

Much work remains to be done before optimum storage temperature regimes can be worked out in relation to other aspects of the storage environment, duration of storage, physiological condition, nursery climate, and species. Especially if it spans the freezing point, a difference in temperature of a few degrees can cause dramatic differences in subsequent performance of planting stock (cf. Cram and Lindquist 1981, Mullin and Laupert 1981).

Unless protected, trees in storage will become desiccated. Much depends on the method of packaging and the ambient relative humidity. Relative humidities in the range of $85-90 \%$ are dangerously low (Deffenbacher and Wright 1954, Wilner and Vaartaja 1958). Ideally the relative humidity should approach $100 \%$.

Stock lifted for storage after indications of flushing have become apparent stores very poorly. It probably should be stored for less than two weeks.

\section{(b) Time of lifting/storing}

Time of lifting, with its great potential for affecting physiolog- ical condition, is even more important in relation to storage than to planting. This is true for both spring- and fall-lifted stock.

In attempts to devise safe schedules for spring-lifting of stock for frozen storage, Mullin (1978b) used a base of $0^{\circ} \mathrm{C}$ and accumulated daily maximum soil temperatures (to the nearest $0.5^{\circ} \mathrm{C}$ ) at $15-\mathrm{cm}$ depth to calculate degree days (DD); he interpreted the evidence to mean that white spruce destined for frozen storage should have accumulated no more than 50 DD before being lifted. The comparable figure for red pine (Pinus resinosa Ait.) was 300 DD.

Fall-lifted stock for overwinter storage generally should have completed the first stage of the dormancy sequence (cf. Cleary et al. 1978) and reached a state variously termed "hardened-off" (Kahler and Gilmore 1961), "winter ripeness" (Anon. 1961), "full dormancy" (Aldhous 1964), etc., that confers on the stock adequate physiological "hardiness" (Stone and Schubert 1959, Aldhous 1964) or "vinterstyrke" (= winter vigor) (Sandvik 1976). This aspect of dormancy progression is particularly clear in the pines, less so in the spruces.

Guides for fall-lifting, developed by Mullin and Parker (1976) at Midhurst in southern Ontario, indicate that jack pine there becomes ready for lifting at about 208 degree-hardening days (DHD), based on the cumulative daily difference between $10^{\circ} \mathrm{C}$ and the daily minimum soil temperature at $15-\mathrm{cm}$ depth. At St. Williams, the southernmost nursery of the Ontario Ministry of Natural Resources, Mullin and Laupert (1981) estimated that white pine (Pinus strobus L.) becomes ready for lifting at 95-100 DHD, whereas previous work at Midhurst, $180 \mathrm{~km}$ to the north, had indicated a figure of about $125 \mathrm{DHD}$ (Mullin and Parker 1976), later revised to 165 DHD (Mullin and Hutchison 1978). For frozen overwinter storage of black spruce, Mullin and Hutchison suggested that a minimum of 167 DHD should be accumulated before lifting.

The relationship between physiological condition and DHD is obviously too complex to be expressed reliably by simple accumulation of temperature differences.

\section{(c) Discussion}

\section{(i) Spring-lifted stock}

Both cool- and frozen-stored spring-lifted stock have been used successfully on occasion in spring and summer plantings, although frozen storage in this context has received less attention than has frozen overwinter storage (Mullin and Reffle 1980).

With reference to cool-stored spring-lifted stock, a large body of evidence (cf. Stoeckeler 1950, Stoeckeler and Jones 1957, Burgar and Lyon 1968, Mullin and Forcier 1976, 1979 , McClain 1976, 1979, 1980, Revel and Coates 1976, Christilaw 1981) justifies some useful generalizations about the main ingredients of success: lifting before flushing has begun, prevention of desiccation, maintenance of a constant temperature within 1 or 2 degrees of freezing, minimization of mold by good temperature control and sanitation, avoidance of crushing and other mechanical damage, and avoidance of longer than necessary periods of storage, generally no more than 8 weeks.

A few specific cases will illustrate some of the main points about the use of frozen-stored spring-lifted stock.

Mullin and Forcier (1976) and Mullin and Reffle (1980) examined the effects of spring lifting date and planting date on $2+0$ jack pine, $3+0$ black spruce, and $3+0$ white spruce after frozen storage, with fresh-lifted controls planted on each planting date for comparison. In all plantings, the earliest (2 May) lifting gave highest average 2 nd-year survival in all species. Plantings that took place after the end of May with early-lifted frozen-stored stock generally gave much higher survival than 
those with fresh-lifted stock. This was particularly true for jack pine: the 2nd-year survival rates for jack pine plantings on 5 July were $32 \%$ among stock that had been fresh-lifted and quick-planted, $84 \%$ among stock that had been lifted on 2 May and frozen-stored for 9 weeks before planting.

In another study, Mullin (1978b) found that outplantings of frozen-stored $3+0$ white spruce were consistently successful to the end of July only with the earliest-lifted ( 25 April) stock.

Sutton (1982) also used frozen-stored $2+0$ jack pine, $3+0$ black spruce, and $3+0$ white spruce in outplantings every 2 weeks from the end of June through the growing season in three successive years on a variety of sites in northern Ontario. Despite variation in planting stock, poor storage environments, and adverse weather, 4th-year results showed a consistent pattern of reasonably good survival and reasonably good growth of survivors among trees planted through July (and in some cases through mid-August), and a rapid decline in both survival and growth rate of survivors for trees planted thereafter. In that study, NPK fertilization at the time of planting was generally detrimental, especially in plantings from midAugust onwards; and tilling merely had the effect of offsetting the detrimental effect of fertilization to some extent.

(ii) Fall-lifted stock

Considerable success has attended the practice of fall lifting of planting stock and holding it in refrigerated storage until the following spring.

Some of the major considerations are well illustrated by Mullin and Parker's (1976) study of the effect of date of fall lifting and temperature of overwinter storage on the performance of spring-planted $3+0$ white spruce and $2+0$ jack pine. There were five lifts, weekly from 19 October through 16 November, after which frozen ground put a stop to the series. Two storage temperatures were used, $-18^{\circ} \mathrm{C}$ and $-4^{\circ} \mathrm{C}$. Nearly all the trees stored at $-18^{\circ} \mathrm{C}$ died. The other stock was planted in shallow furrows in a sparsely sodded field of loamy sand, the jack pine on 9 April, 9 May and 11 June, and the white spruce on 12 April, 17 May and 14 June. Fresh-lifted stock was also planted at each planting. The results clearly show the need for late lifting of jack pine intended for overwinter frozen storage and "indicate that freshly dug spring-lifted trees may give better results for early and mid-season planting, whereas stored [jack pine] may give better results for late planting (although well below the results of spring lifting and midseason planting of unstored stock)". Also, "either freshly dug or stored white spruce, if lifted at the proper time, will give comparable results when used to extend planting into midJune" in the Midhurst area of Ontario.

In studying overwintering storage of red pine, Mullin and Bunting $(1970,1972)$ found that frozen storage was as good as or better than unfrozen, and several packaging methods gave results not significantly different from those given by spring-lifted controls. Of four satisfactory storage treatments, the frozen polybag was the most successful for mid-season planting in the regular spring planting season. Very poor results were obtained with the cool-stored bale-in-polybag packaging treatment.

Natural refrigerated overwinter storage, which offers some advantages that appeal to both nurserymen and forest managers (Mullin 1966), has been used in root cellars and snow caches. Using natural refrigeration in root cellar storage, Jorgensen and Stanek (1962) kept $3+0$ and $2+2$ white spruce in dormant condition for approximately 6 months without apparent detriment to performance after outplanting. Moreover, the stock was highly resistant to spring frost damage.

Mullin (1966) also used natural cold storage for overwintering $3+0$ and $2+2$ stock, both white spruce and red pine, that was raised in a nursery at about the same latitude as the planting site, unlike Jorgensen and Stanek's (1962) stock, which was raised 500 to $800 \mathrm{~km}$ to the south of where it was planted. Inside-bale temperatures fell to $-15^{\circ} \mathrm{C}$ in mid-winter, underlining a potential hazard of uncontrolled refrigeration. First- and second-year survival rates were $91.4 \%$ and $76.2 \%$ for freshly lifted control white spruce and $85.9 \%$ and $65.9 \%$ for stock that had been stored over winter. Unlike Jorgensen and Stanek's (1962) results, Mullin's indicated that frozen-stored stock was damaged by spring frost significantly more than was fresh-lifted stock. Mullin noted that "the stored white spruce... showed a reduction in vigour as measured in terms of survival, susceptibility to damage, and growth"'. Red pine, too, performed more poorly after this overwinter storage than after early spring lifting and fresh planting.

\section{(d) Recommendations}

For pines, lift very late in the fall for overwinter storage, very early in the spring for spring storage, particularly if stock is to be frozen. Avoid temperatures lower than $-2^{\circ} \mathrm{C}$. Minimize mold, desiccation, and depletion of energy reserves. Good handling practice throughout the lifting/planting sequence is essential. For spruces, the importance of lateness in fall lifting is not as apparent as with the pines, but otherwise practices similar to those for pines are recommended. Stored stock can be used to advantage to extend the spring planting season into summer. In the case of the spruces, stored stock can be used to reduce the risk of frost injury in new plantings during the conventional spring planting season.

\section{Conclusions}

There is considerable scope for extending the conventional seasons of planting (Fig. 1). The ideal of lifting apparently dormant stock in the spring and planting it without delay is seldom attainable in practice when large-scale operations are involved. Fall planting can give good results provided that dormancy requirements are met and soils prone to frost heaving avoided. Summer planting of spruces also has good potential but only if handling stresses are minimized. Storage of both fall-lifted and spring-lifted stock offers effective means for extending the spring planting season well into the summer.

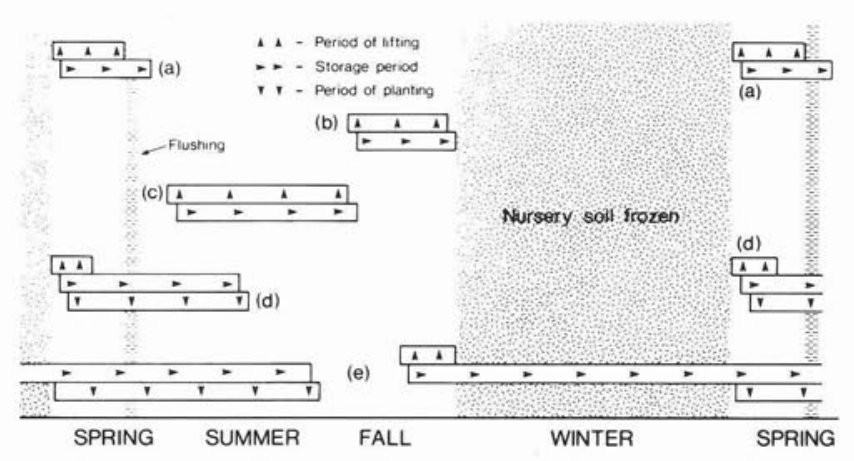

Figure 1. Schematic diagram of bare-root planting season options: (a) spring planting with fresh stock; (b) fall planting with fresh stock; (c) summer planting (spruces) with fresh stock; (d) spring and summer planting with stored spring-lifted stock; and (e) spring and summer planting with stored fall-lifted stock. 


\section{References}

Ackerman, R.F. and H.J. Johnson. 1962. Continuous planting of white spruce throughout the frost-free period. Can. Dep. For., For. Res. Br., Tech. Note 117, 13 p.

Aldhous, J.R. 1964. Cold storage of forest nursery plants: an account of experiments and trials, 1958-63. Forestry $37: 47-63$

Anon. 1961. Lagring og plante behandling. Skogind. Forsk. Foren., Arsberet 1960, 1961: 7-8.

Armson, K.A. White spruce seedlings: the growth and seasonal absorption of nitrogen, phosphorous, and potassium. Univ. Toronto, For. Bull. 6, 37 p.

Baldwin, H.I. 1938a. Comparison of spring and fall planting. Fox For. Note $8,1 \mathrm{p}$.

Baldwin, H.I. 1938b. Planting experiments in the Northeast. J. For. 36: 758-760.

Björkman, E. 1956. Om lagring av tall- och granplantor. Norrlands SkogsFörb. Tidskr. 4: 465-483.

Brown, R.M. 1971. Cold storage of forest plants: a review. Q.J. For. 65: $305-315$

Bunting, W.R. and R.E. Mullin. 1967. Summer and fall planting of jack pine in Ontario suffer high mortality and slower growth after 16 years. USDA For. Serv., Tree Plant. Notes 18: 22-24.

Bunting, W.R. 1977. Discussion. p. 86 in Plantation Establishment Symposium. R.F. Sutton, Ed. Dep. Environ., Can. For. Serv. Sault Ste. Marie, Ont. Symp. Proc. 0-P-5.

Burgar, R.J. and N.F. Lyon. 1968. Survival and growth of stored and unstored white spruce planted through the frost-free period. Ont. Dep. Lands For., Res. Br., Res. Rep. 84, 37 p.

Campbell, A.J. 1977. Hand planting in eastern Ontario. p. 69-70, 85 in Plantation Establishment Symposium. R.F. Sutton, Ed. Dep. Environ., Can. For. Serv., Sault Ste. Marie, Ont., Symp. Proc. 0-P-5.

Christilaw, T.S. 1981. Effect of spring storage in the Dog River storage facility on subsequent growth and survival of $3+0$ black spruce seedlings. Lakehead Univ., Sch. For., undergraduate thesis, $36 \mathrm{p}$.

Cleary, B.D., R.D. Greaves, and P.W. Ouston. 1978. Seedlings. p. 63-97 in Regenerating Oregon's. Forests. B.D. Cleary, R.D. Greaves, and R.K. Hermann, Ed., Oregon State Univ. Extension Serv., Corvallis

Cram, W.H. and C.H. Lindquist. 1981. Overwinter and spring storage of pine and spruce seedlings. For. Chron. 57: 162-164

Crossley, D.I. 1956. The possibility of continuous planting of white spruce throughout the frost-free period. Dep. North. Aff. Nat. Resour., For. Res. Div., Tech. Note 32, 31 p.

Daniel, T.W., J.A. Helms, and F.S. Baker. 1979. Principles of Silviculture, 2nd ed. McGraw-Hill, New York, 500 p.

Decie, T.P. 1962. Planting white spruce throughout the growing season. B.C. For. Serv., Res. Rev., cited by Revel and Coates (1976), orig. not seen.

Deffenbacher, F.W. and E. Wright. 1954. Refrigerated storage of conifer seedlings in the Pacific Northwest. J. For. 52: 936-938

Hawley, R.C. and D.M. Smith. 1954. The Practice of Silviculture Wiley, New York, 525 p.

Hermann, R.K. 1967. Seasonal variation in sensitivity of Douglas-fir seedlings to exposure to roots. For. Sci. 13: 140-149

Hocking, D. and R.D. Nyland. 1971. Cold storage of coniferous seedlings: a review. State Univ. Coll. For. at Syracuse Univ., Appl. For. Res. Inst., Res. Rep. 6, 70 p.

Hopkins, G.M. 1938. Survival of nursery stock after cold storage. Fox For. Notes 11, $1 \mathrm{p}$.

Jorgensen, E. and W.K.L. Stanek. 1962. Overwinter storage of coniferous seedlings as a means of preventing late frost damage. For. Chron. 38: 192-202

Kahler, L.H. and A.R. Gilmore. 1961. Field storage of cold stored loblolly pine seedlings. USDA For. Serv., Tree Plant. Notes 45: 15-16.

Kittredge, J., Jr. 1929. Forest planting in the Lake States. USDA, Bull. $1497,87 \mathrm{p}$.

Köstler, J. 1956. Silviculture [Transl. M.L. Anderson]. Oliver and Boyd, Edinburgh, $416 \mathrm{p}$.

Lavender, D.P. and B.D. Cleary. 1974. Coniferous seedling production techniques to improve seedling establishment. p. 177-180 in Proc. North Am. Containerized For. Tree Seedling Symp., R.W. Tinus, W.I. Stein and W.E. Balmer, Ed. Great Plains Agric. Counc. Publ. 68
LeBarron, R.K., G. Fox, and R.H. Blythe, Jr. 1938. The effect of season of planting and other factors on early survival of forest plantations. J. For. 36: 1211-1215.

Leslie, A.P. 1945. Storage of planting stock over winter. Ont. Dep. Lands For., Res. Rep. 5, 6 p.

Levitt, J. 1980. Responses of Plants to Environmental Stresses, 2nd ed. Vol. 1. Chilling, Freezing, and High Temperature Stresses. Academic Press, New York, $497 \mathrm{p}$

McClain, K.M. 1975. Continuous planting of seedling black spruce. p. 177-194 in Black Spruce Symposium Proc. Dep. Environ., Can. For Serv., Sault Ste. Marie, Ont., Symp. Proc. 0-P-4

McClain, K.M. 1976. Black spruce research at the Northern Forest Research Unit. Paper presented to Ont. Min. Nat. Resour., Thunder Bay District, For. Manage. Staff Meet., 30 Nov.-1 Dec., 8 p. (mimeo).

McClain, K.M. 1979. A review of the possibility of extending the planting season. Ont. Min. Nat. Resour., Northern For. Res. Unit, Thunder Bay, 45 p. (mimeo).

McClain, K.M. 1980. Nursery cultural practices affect post planting performance of white and black spruce. Agron. Abstr.: 203.

McClain, K.M. 1981. Effects of continuous planting on black spruce survival and growth: an interim report. Ont. Min. Nat. Resour., For. Res. Note 24, 4 p.

Mullin, R.E. 1966. Overwinter storage of baled nursery stock in northern Ontario. Commonw. For. Rev. 45: 224-230.

Mullin, R.E. 1968. Comparisons between seedlings and transplants in fall and spring plantings. Ont. Dep. Lands For., Res. Br., Res. Rep. 85,40 p.

Mullin, R.E. and W.R. Bunting. 1970. Frozen overwinter storage for red pine. USDA For. Serv., Tree Plant. Notes 21(4): 8-9.

Mullin, R.E. 1971. Some effects of root dipping, root exposure and extended planting dates with white spruce. For. Chron. 47: 90-93.

Mullin, R.E. and W.R. Bunting. 1972. Refrigerated overwinter storage of nursery stock. J. For. 70: 354-358

Mullin, R.E. 1974a. Some planting effects still significant after 20 years. For. Chron. 50: 191-193.

Mullin, R.E. 1974b. Effects of root exposure on establishment and growth of outplanted trees. p. 229-242 in Internatl. Symp. Ecol. and Physiol. of Root Growth Proc., Akademie-Verlag, Berlin.

Mullin, R.E. and L. Forcier. 1976. Effect of lifting and planting dates on survival and growth of spring stored nursery stock. Ont. Min. Nat. Resour., Div. For., For. Res. Br., For. Res. Note 3, 4 p.

Mullin, R.E. and J.D. Parker. 1976. Provisional guidelines for fall lifting for frozen overwinter storage of nursery stock. For. Chron. 52: 22-25.

Mullin, R.E. 1978a. Root exposure, root dipping, and extended spring planting of white pine seedlings. For. Chron. 54: 84-87.

Mullin, R.E. 1978b. Tests of frozen spring storage for white spruce and red pine planting stock. USDA For. Serv., Tree Plant. Notes 29: 26-29.

Mullin, R.E. and R.E. Hutchison. 1978. Lifting guides for frozen overwinter storage of black spruce at Swastika Nursery. Ont. Min. Nat. Resour., Nursery Notes 55, 6 p.

Mullin, R.E. and L. Forcier. 1979. Spring lifting and storage of jack pine at Swastika Nursery. Ont. Min. Nat. Resour., Nursery Notes $59,7 \mathrm{p}$

Mullin, R.E. and R.J. Reffle. 1980. Effects of dates of lifting and planting on success of frozen spring storage at Swastika Nursery. Ont. Min. Nat. Res., Nursery Notes 66, 5 p.

Mullin, R.E. and R.E. Laupert. 1981. Cold and frozen overwinter storage of white pine at St. Williams Nursery. Ont. Min. Nat Resour., Nursery Notes 70, 5 p

Navratil, S., R.B. Sedor, and A.D. Wynia. 1975. Effects of container type on the physiological and pathological quality of planting stock in cold storage. Lakehead Univ., Sch. For. Rep., 44 p.

Nyland, R.D. 1974. Cold storage delays flushing of conifers. State Univ. Coll. For. at Syracuse Univ., Appl. For. Res. Inst., Res. Note 10, 2 p.

Revel, J. and H. Coates. 1976. Planting of white spruce throughout the growing season on high site areas in the Sub-boreal Forest Region of British Columbia. B.C. For. Serv., Res. Div., Rep. E.P. $668,37 p$

Rudolf, P.O. 1950. Forest plantations in the Lake States. USDA For Serv., Tech. Bull. 1010, $171 \mathrm{p}$

Ryker, R.A. 1976. When to plant. p. 185-192 in Tree Planting in the 
Inland Northwest. D.M. Baumgartner and R.J. Boyd, Ed. Proc. of Conf. at Wash. State Univ. Feb. 17-19, 1976, Wash. State Univ. Coop. Exten. Serv.

Sandvik, M. 1976. Vinterstyrke hos gran. 1. Effekt av opptakstid nedkjøling og opptining ved fryselagring av granplanter. Norw. For. Res. Inst. Rep. 32: 340-355

Schmidt-Vogt, H. 1963. [First experiments in delaying growth of forest plants by cold storage.] Forst. -und Holzw. 19: 85-86. For Abstr. 25: 5024, orig. not seen.

Schopmeyer, C. 1940. Survival in forest plantations in the northern Rocky Mountain region. J. For. 38: 16-24.

Schubert, G.H. and R.S. Adams. 1971. Reforestation Practices for Conifers in California. Calif. Res. Agency, Dep. Conserv., Div. For., Sacramento, $359 \mathrm{p}$

Show, S.B. 1930. Forest nursery and planting practice in the California pine region. USDA, Agric. Circ. 92, $74 \mathrm{p}$.

Simon, C.L. 1961. Effects of lifting date, cold storage and grading on survival of some coniferous nursery stock. J. For. 59: 449-450.

Sinclair, C. and R.J. Boyd. 1973. Survival comparisons of three fal and spring plantings for four coniferous species in northern Idaho. USDA For. Serv., Res. Pap. INT-139, 20 p.

Slayton, S.H. 1970. Storing baled red pine, black spruce, and white spruce overwinter feasible in Upper Michigan. USDA For. Serv., Tree Plant. Notes 21: 15-17.

Stiell, W.M. 1976. White spruce: Artificial Regeneration in Canada. Dep. Environ., Can. For. Serv., Ottawa, Ont. Int. Rep. FMR-X-85. $275 \mathrm{p}$.
Stoeckeler, J.H. 1950. How long can conifers be held in spring by cold storage. USDA For. Serv., Lake States For. Exp. Stn., Tech. Note 343, $1 \mathrm{p}$.

Stoeckeler, J.H. and G.W. Jones. 1957. Forest nursery practice in the Lake States. USDA, Agric. Handb. 110, 124 p.

Stone, E.C. and G.H. Schubert. 1959. The physiological condition of ponderosa pine (Pinus ponderosa Laws.) planting stock as it affects survival after cold storage. J. For. 57: 837-841.

Sutton, R.F. 1968. Ecology of young white spruce (Picea glauca [Moench] Voss). Ph.D. thesis, Cornell Univ., 500 p. Univ. Microfilms 68-11645.

Sutton, R.F. 1969. Form and Development of Conifer Root Systems, Commonw. For. Bur., Tech. Comm. 7, 131 p.

Sutton, R.F. 1982. Plantation establishment in the boreal forest: planting season extension. Dep. Environ., Can. For. Serv., Sault Ste. Marie, Ont. Report 0-X-344, 129 p.

Toumey, J.W. and C.F. Korstian. 1942. Seeding and Planting in the Practice of Forestry. Wiley, New York, 520 p

Williams, R.D. and Rambo, R. 1967. Overwinter cold storage of red and white pine transplants successful in northern Indiana. USDA For. Serv., Tree Plant. Notes 18: 21-23.

Wilner, J. and Vaartaja, O. 1958. Prevention of injury to tree seedlings during cellar storage. For. Chron. 34: 132-138.

Yli-Vakkuri, P., P. Räsänen, and A. Hilli. 1968. Taimien talvivarastoinnista ja sen vaikutuksesta männyn taimien istutuskelpoisuuteen. Acta For. Fenn. 88: 1-40.

\section{TTS - SOIL PREPARATION EQUIPMENT}

\section{The most popular line of scarifiers, by far, from Finland}

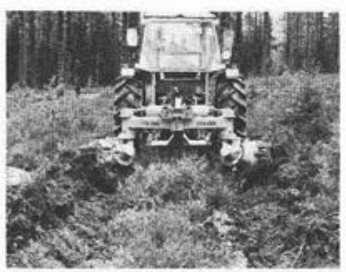

TTS-10

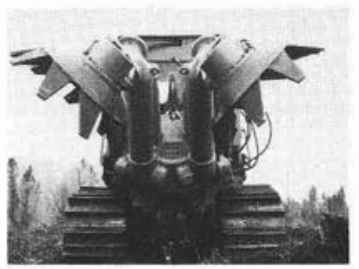

TTS-Delta

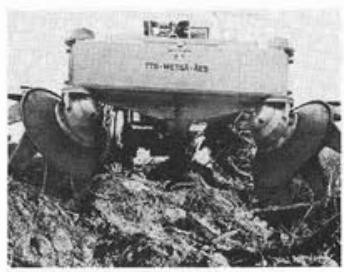

TTS-35

For further information contact:

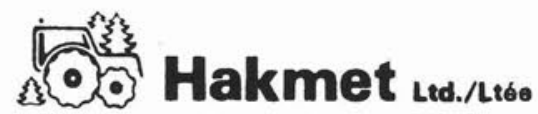

Dorion, Quebec (514) 455-6101

Scarborough, Ontario (416) 431-3509 